\title{
EFFECT OF CORPORATE SOCIAL RESPONSIBILITY DISCLOSURE ON FINANCIAL PERFORMANCE WITH AUDIT QUALITY AS A MODERATING VARIABLE
}

\author{
Kartika Dewi'; Monalisa ${ }^{2}$ \\ ${ }^{1,2}$ Accounting and Finance Department, Faculty of Economics and Communication, Bina Nusantara University, \\ Jln. K.H. Syahdan No 9, Jakarta Barat, DKI Jakarta, 11480, Indonesia \\ 1,2kdewi@binus.edu
}

Received: $27^{\text {th }}$ January 2016/ Revised: $8^{\text {th }}$ March 2016/ Accepted: $16^{\text {th }}$ August 2016

How to Cite: Dewi, K. \& Monalisa. (2016). Effect of Corporate Social Responsibility Disclosure on Financial Performance with Audit Quality as a Moderating Variable. Binus Business Review, 7(2), 149-155. Http://dx.doi.org/10.21512/bbr.v7i2.1687

\begin{abstract}
This article aimed to examine the influence of Corporate Social Responsibility (CSR) disclosure to the financial performance proxy on Return on Assets (ROA), Return on Equity (ROE), and company value proxy on Price to Book Value (PBV) empirically as well as knowing the existence of the audit quality as moderating variable whether it will affect the relationship between CSR disclosure on ROA, ROE, and PBV. The object of this study was mining companies listed on the Indonesia Stock Exchange period 2010-2012. The sample was selected using a purposive sampling method and obtained samples as many as 26 companies with a total data of 78 data. Hypothesis testing methods used were simple regression analysis and moderated regression analysis. The results of this study show that Corporate Social Responsibility (CSR) disclosure has an effect on ROA, but has no effect on ROE and PBV, and audit quality as a moderating variable cannot affect the relationship of CSR disc losure on ROA, ROE, and PBV.
\end{abstract}

Keywords: corporate social responsibility, Return on Assets (ROA), Return on Equity (ROE), Price to Book Value (PBV), audit quality

\section{INTRODUCTION}

Financial Statement is used to report company performance to external and internal users. The users or readers can be mentioned as stakeholders. Without hesitation, all stakeholders expect financial statement is in good condition, yields high net profit. High net profit can be returned to stakeholders in dividend or reinvested back to the company for further purposes in the future. Good Corporate Governance is used to help directors to monitor daily operation in the company. Good Corporate Governance has five principles which are Transparency, Accountability, Responsibility, Integrity, Fairness. In principle of Responsibility states that a company must be responsible to all stakeholders especially the society and environment through Corporate Social Responsibility (CSR). According to Susilawati (2009), CSR is caring, responsible and sensitive to others needs in an area which the company is operating on. Not only has the company been profited from the taking of natural resources, but also from the society who live in that area. CSR is a social role of the corporation that something has to be returned to the society. CSR is in the form of free education, constructi on of hygiene facility (MCK-Mandi Cuci Kakus), and public facility that can be used such as the library, park, replanting trees and other useful activities for everyone in that society. Company image can be increased through this CSR program. In return, the image of the company can be recognized, and thus, make the customers prefer to buy products or service from the companies that have done the CSR programs. In return, company sales will increase too.

CSR is a disclosure of an annual report. When first time introduced, CSR is only based on single bottom line (corporate value), but nowadays, CSR is 
based on triple bottom lines (corporate value, social and environment) based on Daniri (2008 in Badjuri, 2011). Issues on CSR are increasing, and popular that Indonesian Government also takes into action to issue fundamental law: Undang-undang No. 40 Tahun 2007 (Law No. 40 Year 2007) dated Augustus 16, 2007. The Law says all corporations carrying all operations have a relation to natural resources should do CSR in the place where the company is built. With the fundamental law is established and enforced, many companies start to obey that law.

CSR disclosure can improve company performance and its image for a long period. The company that runs with good business etiquette and well management can increase its sustainability. Increase customer reliability on company brand can boost company sales and in return, all stakeholders will get a positive win-win solution. CSR can fill the gap between corporation and society. Investors are more interested in company which has CSR compare to those which has not. With good and consistent CSR, the company's sales are expected to increase and in the bottom, the net profit will increase too. Financial ratio is used to measure company profitability such as Return on Assets (ROA) and Return on Equity (ROE). Company value can be measured using Price to Book Value (PBV). All ratios will be published in the annual report, and then it will be examined by external auditors. External auditors will state its opinion regarding financial performance. That opinion can increase investor confidence in purchase more shares. Investors and creditors believe a good accounting firm can detect manipulation on financial statements.

Candrayanthi and Saputra (2013) stated that CSR has a positive influence against ROA, ROE, negative influence against Net Profit Margin NPM. CSR has positive influenced on company performance and value (Wibowo, 2012; Bidhari, Salim, \& Aisjah, 2013). Putra, Rasmini, and Astika (2013) said that CSR has positive influenced on PBV. Several types of research have different opinion done by Yaparto, Frisko, and Eriandini (2013) said that CSR did not influence on ROA, ROE, and Earning per Share. Last, but not the least, is research done by Ahalik, Utaminingtyas, and Utami (2010). They stated that CSR and Voluntary Disclosure did not have an influence on company value which measured using PBV ratio.

Many researches with different results are used to examine CSR effect on company performance using ROA, ROE, and PBV. The difference from previous research is the size of accounting firm that is categorized between big four and non big four as a moderating variable. A moderating variable is used to strengthen or weaken the relation between independent variables. This research uses mining company as a sample because mining company exploits natural resources both directly and indirectly. By using the arguments above, the relation between CSR, ROA, ROE, PBV and audit quality as moderating variable wanted to be examined.
Signal theory stated that the company will have maximal incentive when disclosing all information to external parties. Based on signaling theory, company will get better image and reputation if it has full disclosed compare to other company which has not. According to Rustiarini (2010), companies voluntarily have full disclosure with the expectation to obtain good reputation and higher company value.

Legitimacy theory stated that a company has a social contract wi th society and environment where it is built. Therefore, the company engages CSR to legitimate its action, to get approval from the society where the corporation was built. Society wants to know how a company operated on, with monitoring from society; the company will operate within boundaries, safe conduct for everything. The company tends to disclose environment to get a positive reaction from the society based on Badjuri (2011). With a good CSR disclosure, it is expected to get legitimating from the society to increase performance and company value. Based on Ghozali and Chariri (2007), in Rinaldy (2011), only the company which tries to get legitimating from society will sustain.

Stakeholder theory mentioned that company should give attention to both shareholders and stakeholders. All stakeholders were influenced and influenced company activities and action directly and indirectly. According to Hadi (2011), if the company does not consider its stakeholders, they will protest and try to eliminate its shareholders.

There are many definitions for CSR, Fundamental law No. 40 Year 2007 about corporation stated that Corporate Social Responsibility is a company commitment to involve in continuously economic development to increase the quality of life and useful environment both community and company. ISO 26000:2010 Guidance on Social Responsibility has the definition on CSR, CSR is meant to be a socially responsible organization, and it is important for a company to adopt this position. Through transparency and ethical behavior, a company can contribute sustainable development, take into account expectation from stakeholders, compliance with laws, integrated into organization and practices in the relationship.

Global Reporting Initiative (GRI) is an independent international organization that helps business, government, and other organization understand and communicate the impact of business on critical sustainability issues. GRI has a standard framework to report indicators for CSR report. The purpose of GRI is to make CSR report uniform and comparable as financial reporting.Definition of CSR, based on GRI is sustainability report integrates social, economic and environment. Based on GRI, there are six indicators for CSR disclosure which are economic performance indicator, environment performance indicator, labor practices \& decent work performance indicator, the human rights performance indicator, society performance indicator, product responsibility performance indicator. Based on Cheng, Megawati and 
Christiawan (2011), current economic and decision making cannot be found at financial statements because a bad or good company performance cannot be reflected in net income.

The result from company performance is net income. This research uses ROA and ROE to measure company performance. Gibson (2011) stated that "Return on Assets measures the firm's ability to utilize its assets to create profits by comparing profits with the assets that generate the profits." The higher the ratio is, the better it is. It means the company is very efficient in utilizing its assets, creating more value for shareholders using assets employed. The formula for ROA is as follow:

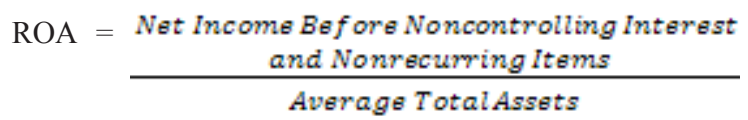

Gibson (2011) said that "The return on total equity measures the return to both common and preferred stockholders." It means the net income return as the percentage of shareholders equity. Shareholders consist of common stock and preferred stock. The higher the ratio, the better. It means the company is efficient to generate income from the money invested in the company. The formula of ROE is as follows:

$$
=\frac{\text { NoE Income Before Nonrecurring Items - Dividends on Redeemable Preforred Stock }}{\text { Average Total Equity }}
$$

PBV is a ratio used to compare stock's market value to stock's book value. The higher the PBV ratio, the better the company's value. Every time the market value change, the ratio of PBV will change too. With high PBV ratio means high market value of the stock and low PBV ratio means cheap stock value. The formula for PBV, according to Tryfino (2009), is as follows:

$$
P B V=\frac{\text { market value of stock }}{\text { book value of stock }}
$$

According to Belkaoui (2006), the definition of audit quality is a small probability financial statements will misinterpretation, contains error or misconduct. In other words, audit quality is assurance that auditor gives appropriate audit opinion. Audit risk is reduced by using high-quality audit performed by capable auditors. The size of an accounting firm is taking into consideration. In several studies, the size of the accounting firm is used to measure audit quality. The size of an accounting firm is divided into two types, i.e. big four and nonbig four. The big four in Indonesia is as follows: (1) KAP Osman Bing Satrio - Deloitte Touche Tohmatsu, (2) KAP Tanudiredja, Wibisana \& Rekan - Pricewaterhouse Coopers, (3) KAP Purwantono, Suherman \& Surja - Ernst \& Young, (4) KAP Siddharta dan Widjaja - Klynveld Peat Marwick Goerdeler (KPMG).

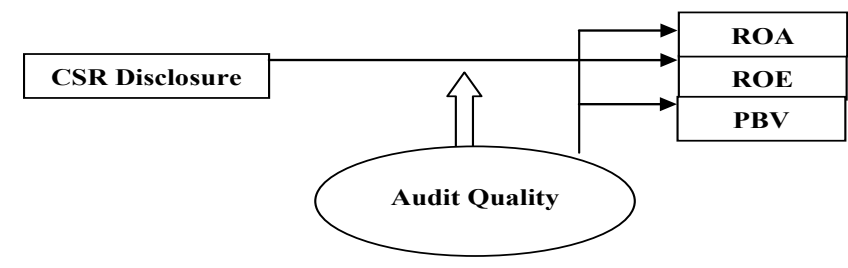

Figure 1 Framework between Variables

CSR Disclosure is independent variable because independent variable is a stand-alone variable, cannot be changed, an independent variable determined the value of dependent variable. Dependent variables consist of ROA, ROE, and PBV also moderating variable is audit quality, as seen in Figure 1.

If the society trust and is loyal on company's products, then the company performance will increase and at the end net profit will go up too. Company with CSR disclosures will get more respect from society, and we believe there is a positive relation between CSR disclosure and net income for ROA. The proposed hypothesis is as follows:

$\mathrm{Ha}_{1}$ : CSR Disclosure has a positive relation on ROA.

Most companies in modern society are aware that environment and social issue are very important. Full disclosure of CSR will give positive assurance for all shareholders and stakeholders. Full disclosure will gain trust and loyalty for readers. If readers trust, readers will buy company's products. This situation will increase company net profit. The authors believe there is a positive relation between CSR disclosure and net income for ROE. The proposed hypothesis is as follow:

$\mathrm{Ha}_{2}$ : CSR Disclosure has a positive relation on ROE.

Company purpose is to increase company value. That value will increase continuously and the value should sustain for indefinitely. CSR disclosure will react differently to investors. Those different reactions will result in company value reflected on market value, volume transaction. The authors believe there is a positive relation between CSR disclosure and PBV. The proposed hypothesis is as follows:

\section{$\mathrm{Ha}_{3}$ : CSR Disclosure has positive relation PBV.}

Annual Report is a complete package about a company contains all information useful for its readers. That information published to users are very important to make a decision. The most important information is Financial Statements audited by a reputable accounting firm in the form of the audit opinion. Audit procedures done by external auditors give good assurance for readers to trust. Good audit procedures also reduce information asymmetric between management and stakeholders. The authors expect high-quality auditor can detect fraud better so financial statements will in a good shape. Hamid (2013) proved KAP (Accounting 
Firm) big four has more quality than KAP nonbig four. This means audit quality is influenced by company performance. In this research quality audit is used as moderating variable against CSR disclosure with ROA, ROE, and PBV. Quality audit shows by KAP big four and non big four.

Based on argument above, we construct hypothesis as follow:

$\mathrm{Ha}_{4}$ : Audit Quality will moderating CSR Disclosure against ROA.

$\mathrm{Ha}_{5}$ : Audit Quality will moderating CSR Disclosure against ROE.

$\mathrm{Ha}_{6}$ : Audit Quality will moderating CSR Disclosure against PBV.

\section{METHODS}

Data used in this research is secondary data. All information are collected from Annual Report published in www.idx.co.id All financial statements are audited either with big four or nonbig four. All samples are in the mining industry and listed in Bursa Efek Indonesia (BEI) for period of 2010-2012. Information is also gathered from the company website. Samples collected using purposive samplings; it means that some criteria are selected for the sample to be used in this research according to the purpose of this study. Regression test is used to test the hypothesis. Statistical tool used for this research is SPSS version 21. Quantitative analysis is used to test classic assumption (normality, heteroscedasticity, multi-collinearity, auto-correlation), T-test and F-Test.

\section{RESULTS AND DISCUSSIONS}

Based on the samples criteria on the mining industry, total sample is 78 data derived from 26 companies times three years. Descriptive statistic testing is tested to give descriptive on data for minimum value, maximum value, mean, standard deviation, as well as to understand variables used in this research, as seen in Table 1.

Table 1 Result of Descriptive Statistics

Descriptive Statistics

\begin{tabular}{lccccr}
\hline & N & Minimum & Maximum & Mean & $\begin{array}{c}\text { Std. } \\
\text { Deviation }\end{array}$ \\
\hline CSR (X1) & 63 & 0,07 & 1,00 & 0,4754 & 0,31810 \\
KAP (X2) & 63 & 0,00 & 1,00 & 0,5714 & 0,49885 \\
X1*X2 & 63 & 0,00 & 1,00 & 0,4286 & 0,49885 \\
ROA (Y1) & 63 & $-0,30$ & 0,45 & 0,0755 & 0,13846 \\
ROE (Y2) & 63 & $-0,98$ & 0,62 & 0,1085 & 0,29298 \\
PBV (Y3) & 63 & 0,41 & 9,55 & 2,4740 & 2,02280 \\
Valid N & 63 & & & & \\
(list wise) & & & & & \\
\hline
\end{tabular}

Classical Test Assumption in this research is normality test, heteroscedasticity test, multicollinearity test, and autocorrelation test. First time running the data, data was not normal then the authors found the outliers and erased five companies, and it was run again, and the data was normal. Five companies which were erased times three years equal 15 data. Eligible data used in this research is 63 data derived from 21 companies times three years.

Normality test is used to make sure all data is in a normal distribution. All six hypotheses have normal distribution are showed by plotting data distributed around the diagonal line and follow its line. This regression is eligible for further test. Heterosc edasticity means the variance of error term is constant. The existence of heteroscedasticity is a major concern in regression analysis. According to Ghozali (2013), good regression analysis will not result in homoscedasticity or heterosc edasticity. All six hypotheses have homoscedasticity.

Multicollinearity test is used to test correlation between independent variables. To know which variable makes collinearity is used Variance Inflation Factor (VIF). Test result with VIF less than 10 means no collinearity between independent variables. Our results for multicollinearity are: variable CSR is 2,268; variable $\mathrm{KAP}$ is 2,288 , and variable $\mathrm{X} 1 * \mathrm{X} 2$ is 3,641 . All VIF value is less than 10; thus it can be said that there is no colinearity in our samples. Autocorrelation test in this research is using Durbin-Watson. This is to detect if autocorrelation is present. Autocorrelations mean that adjacent observations are correlated. If they are correlated, then least-squares regression underestimates standard error of coefficients. Based on the test on autocorrelation value $\mathrm{D}-\mathrm{W}$ for model 1 is 1,742 ; model 2 is 1,675 , and model 3 is 1,651 . Based on table for Durbin-Watson (for 63 samples, $\mathrm{k}$ $=1, \alpha=0,05$ ), value for $\mathrm{dL}=1,5599$ and value for $\mathrm{dU}=1,6243$ so value for $4-\mathrm{dU}$ is 2,3757 , so value for $\mathrm{D}-\mathrm{W}$ model 1, 2, and 3 in between du until 4-du, it can be concluded that model 1,2 , and 3 there is no autocorrelation Value D-W for model 4 is 1,837 ; model 5 is 1,832 ; and model 6 is 1,780 . Based on table DurbinWatson (for 63 samples, $\mathrm{k}=3, \alpha=0,05$ ), value for $\mathrm{dL}=1,4943$ and value for $\mathrm{dU}=1,6932$ so value for 4 -dU is 2,3068, value $\mathrm{D}-\mathrm{W}$ for model 4,5 , and 6 are between du until 4-du, it can be concluded that model 4,5 , and 6 have no auto-correlation. The coefficient of determination test is used to indicate how well data fit in statistical model (goodness of fit). A coefficient determination is symbolized with $\mathrm{R}^{2}$.

Table 2 Result of The Coefficient Determination $\left(\mathrm{R}^{2}\right)$

\begin{tabular}{lc}
\hline \multicolumn{1}{c}{ Regressi on Model } & R Square $\left(\mathbf{R}^{2}\right)$ \\
\hline Model 1 (CSR-ROA) & 0,103 \\
Model 2 (CSR-ROE) & 0,042 \\
Model 3 (CSR-PBV) & 0,048 \\
Model 4 (CSR-KAP-ROA) & 0,235 \\
Model 5 (CSR-KAP-ROE) & 0,115 \\
Model 6 (CSR-KAP-PBV) & 0,108 \\
\hline
\end{tabular}

Table 2 explains that the value of $\mathrm{R}$ Square 
for model 1 is 0,103 or $10,3 \%$ means that the dependent variable which is ROA (Y1) its variation can be explained by the CSR variable (X1) while the remaining $89,7 \%$ is explained by variables outside variables used. Value R-square for model 2 of 0,042 means that $4,2 \%$ of ROE dependent variable (Y2) its variation can be explained by the CSR variable (X1) while the remaining $95,8 \%$ is explained by variables outside variables used. Value R-square for model 3 is 0,048 or $4,8 \%$ means that the dependent variable is PBV (Y3) its variation can be explained by the CSR variable (X1) while the remaining $95,2 \%$ is explained by variables outside variables used. Value R-square for model 4 for 0,235 or $23,5 \%$ means that the dependent variable is $23,5 \%$ ROA (Y1) its variation can be explained by the CSR variable (X1), KAP (X2) and $\mathrm{X} 1 * \mathrm{X} 2$ while the remaining $76,5 \%$ is explained by variables outside variables used. Value R-square for model 5 is 0,115 or $11,5 \%$ means that the dependent variable is $11,5 \%$ ROE (Y2) its variation can be explained by the CSR variable (X1), KAP (X2) and $\mathrm{X} 1 * \mathrm{X} 2$, while the remaining $88,5 \%$ is explained by variables outside variables used. Value R-square for model 6 is 0,108 means that $10,8 \%$ dependent variable is the PBV (Y3) its variation can be explained by the $\mathrm{CSR}$ variable (X1), $\mathrm{KAP}(\mathrm{X} 2)$ and $\mathrm{X} 1 * \mathrm{X} 2$, while the remaining $89,2 \%$ is explained by variables outside variables used.

T-tests were conducted to examine whether there is a partial or individual influence of each independent variable on the dependent variable. The decision is to compare the value of significance. Criteria for acceptance and rejection of the hypothesis are: (1) If significance $>0,05$, Ho is accepted or $\mathrm{Ha}$ is rejected, which means there is no significance influence between one independent variable against dependent variables. (2) If significance $<0,05$ the authors reject Ho or accept Ha, means there is significance influence between one independent variable against dependent variables, as seen in Table 3.

Table 3 Conclusion from T-test

\begin{tabular}{|c|c|c|c|c|}
\hline $\begin{array}{c}\text { Model } \\
\text { Regression }\end{array}$ & $\mathbf{t}$ & Sig & Decision & Decision from T-test \\
\hline Model 1 & 2,643 & 0,010 & Reject $\mathrm{Ho}_{1}$ & CSR Disclosure significant influence against ROA \\
\hline Model 2 & 1,641 & 0,106 & Accept $\mathrm{Ho}_{2}$ & CSR Disclosure no significant influence on ROE \\
\hline Model 3 & 1,763 & 0,083 & Accept $\mathrm{Ho}_{3}$ & CSR Disclosure no significant influence on PBV \\
\hline Model 4 & $-0,437$ & 0,664 & Accept $\mathrm{Ho}_{4}^{3}$ & Quality Audit does not moderate the influence of CSR disclosure on ROA \\
\hline Model 5 & 0,283 & 0,778 & Accept $\mathrm{Ho}_{5}^{4}$ & Quality Audit does not moderate the influence of CSR disclosure on ROE \\
\hline Model 6 & $-1,123$ & 0,266 & Accept $\mathrm{Ho}_{6}^{3}$ & Quality Audit does not moderate the influence of CSR disclosure on PBV \\
\hline
\end{tabular}

Table 4 Conclusion from $\mathrm{F}$ test

\begin{tabular}{cccl}
\hline $\begin{array}{c}\text { Model } \\
\text { Regression }\end{array}$ & F & Sig & \multicolumn{1}{c}{ Decision from F test } \\
\hline Model 1 & 6,985 & 0,010 & CSR Disclosure significant influence against ROA \\
Model 2 & 2,692 & 0,106 & CSR Disclosure no significant influence ion ROE \\
Model 3 & 3,108 & 0,083 & CSR Disclosure no significant influence on PBV \\
Model 4 & 6,040 & 0,001 & CSR disclosure, KAP, dan $\mathrm{X}_{1}^{*} \mathrm{X}_{2}$ together significant influence against ROA \\
Model 5 & 2,562 & 0,063 & CSR disclosure, KAP, dan $\mathrm{X}_{1} * \mathrm{X}_{2}$ together no significant influence against ROE \\
Model 6 & 2,373 & 0,079 & CSR disclosure, KAP, dan $\mathrm{X}_{1} * \mathrm{X}_{2}$ together no significant influence against PBV \\
\hline
\end{tabular}

Based on analysis simple regression linier for model 1,2 and 3 as well as analysis moderating regression or interaction test for model 4,5 , and 6 . Thus, the equations can be made as follow:

Model 1: $\mathrm{Y}_{1}=0,009+0,140 \mathrm{X}_{1}$

Model 2: $Y_{2}^{1}=0,018+0,189 X_{1}^{1}$

Model 3: $\mathrm{Y}_{3}^{2}=1,808+1,400 \mathrm{X}_{1}$

Model 4: $Y_{1}^{3}=-0,016+0,057 \mathrm{X}_{1}+0,132 \mathrm{X}_{2}-0,026$ $\mathrm{X}_{1}^{*} \mathrm{X}_{2}$

Model 5: $Y_{2}=-0,004-0,001 X_{1}+0,169 X_{2}+0,039$ $\mathrm{X}_{1}^{*} \mathrm{X}_{2}$

Model 6: $Y_{3}=1,426+1,378 X_{1}+1,490 X_{2}-1,069$ $\mathrm{X}_{1} * \mathrm{X}_{2}$

Description:

$\mathrm{Y}_{1}=\mathrm{CSR} ; \quad \mathrm{Y}_{2}=\mathrm{ROE} ; \quad \mathrm{Y}_{3}=\mathrm{PBV} ;$

$\mathrm{X}_{1}^{1}=\mathrm{CSR} ; \quad \mathrm{X}_{2}^{2}=\mathrm{KAP}$
F-test was conducted to test whether all the independent variables included in the model have influence together (simultaneously) on the dependent variable. This test was conducted using significance level $0,05(\alpha=5 \%)$.

Criteria for accepting and rejecting hypotheses are: (1) If significance $>0,05$ we accept Ho or reject $\mathrm{Ha}$, means regression coefficient is not significance which signifies there is no significant influence of all independent variable s against dependent variable. (2) If significance $<0,05$, Ho is rejected or Ha is accepted, which means that regression coefficient is significance. This implies that there is significant influence between all independent variables against dependent variable.

Based on testing of six hypotheses that have been mentioned previously, there are several conclusions that can be considered. First, the result 
from the first hypothesis shows that CSR disclosure has significance influence against ROA. This result agrees with the result from Almar, Rachmawati, and Murni (2012), Candrayanthi and Saputra (2013), Wibowo (2012) as well as Bidhari, Salim, and Aisjah (2013). They all said CSR disclosure has positive influence against company profitability which proxy with ROA. Therefore, it can be said that the more CSR proxy is disclosed with ROA; the higher the company performance will be. CSR Disclosure is not consider ed as wasting money but rather on long-term investing.

The result from the second hypothesis shows that CSR disclosure has no significance influence against ROE. This result agrees with the result from Yaparto, Frisko, and Eriandini (2013) who stated that CSR disclosure does not have a significant influence on company profitability which proxy with ROE. This may be because investors have a low perception on CSR disclosures. Usually, the company does CSR because it obligates, something the company must do instead of voluntarily or the company is afraid to get a penalty from the government because public/ listed company have to disclose its CSR according to UU Perseroan Terbatas No. 40 Tahun 2007 (Law of Limited Company No. 40 Year 2007).

The result from the third hypothesis showed CSR disclosure has no significance influence against PBV. This result did not agree with the result from Cokorda, Rasmini, and Astika (2013) they all said CSR disclosure has a significant influence against PBV. Our research agrees with the research from Ahalik, Utaminingtyas, and Utami (2010) which said CSR does not have a significant influence on company value proxy with PBV. It means up and down company value did not have relation with CSR disclosure. It may cause by no standard reporting for CSR; not all companies applied GRI reporting; some companies disclose a lot of information and the other hand some of them disclose very little or simply investors do not look into CSR disclosure, the decision to invest in shares do not come from CSR disclosure.

The results from the fourth, fifth and sixth hypothesis show audit quality does not moderate the influence of CSR disclosure against ROA, ROE, and PBV. From previous research done by Karim (2010), it can be acquired that there is positive significance influence between audit quality and company value. Audit quality is proxy with the accounting firm in big four. Audit quality usually influenced by the scope of examination. Wider scope of examination will result in more credibility result. The previous study conducted by Ziaee (2014) used audit quality as independent variable. He said that audit quality has positive influence on company performance. Based on the study, the quality audit does not moderate the influence of CSR disclosure on ROA, ROE, and PBV. It may cause size of KAP does not influence company in disclose its CSR. All of the samples audited by big four or nonbig four have disclosed its CSR but the amount of information disclosed is not uniform, as seen in Table 4.

\section{CONCLUSIONS}

There are several results that can be obtained from this research. (1) CSR disclosure has a significant influence on ROA. (2) CSR disclosure has no significant influence on company performance proxy with ROE. (3) CSR disclosure has no significant influence on company value proxy with PBV. (4) Audit quality as a moderating variable cannot be influenced by CSR disclosure against company performance proxy with ROA. (5) Audit quality as moderating variable cannot be influenced by CSR disclosure against company performance proxy with ROE. (6) Audit quality as moderating variable cannot be influenced by CSR disclosure against company value proxy with PBV.

Suggestion for further research is to expand more samples and different types of industry listed in Bursa Efek Indonesia and if possible to use foreign company. Financial Ratio analysis can be added in addition to statistical analysis and compare the result with the same industry so it will be more accurate. Thus, it can be said that CSR has many positive values for the company, increases the image, engages with employees and customers.

\section{REFERENCES}

Ahalik, U. T. H., \& Utami, W. (2010). Relationship Between Corporate Social Responsibility and Voluntary Disclosure to Firm Value (Study at Public Company Listed in LQ 45). Jurnal Telaah Akuntansi dan Bisnis, 1(2), 37-56.

Almar, M., Rachmawati, R., \& Murni, A. (2012, March 27). Pengaruh Pengungkapan Corporate Social Responsibility (CSR) Terhadap Profitabilitas Perusahaan. Seminar Nasional Akuntansi \& Bisnis. Proceedings, (56), 514-526.

Badjuri, A. (2011). Faktor-faktor Fundamental, Mekanisme Corporate Governance, Pengungkapan Corporate Social Responsibility. Jurnal Dinamika Keuangan dan Perbankan, 3(1), 38-54.

Belkaoui, A. R. (2006). Teori Akuntansi (5 $5^{\text {th }}$ ed.). Jakarta: Salemba Empat.

Bidhari, S. C., Salim, U., \& Aisjah, S. (2013). Effect of Corporate Social Responsibility Information Disclosure on Financial Performance and Firm Value in Banking Industry Listed at Indonesia Stock Exchange. European Journal of Business and Management, 5(18), 39-46.

Candrayanthi, A. A. A., \& Saputra, I. D. G. D. (2013). Pengaruh Pengungkapan Corporate Social Responsibility Terhadap Kinerja Perusahaan (Studi Empiris Pada Perusahaan Pertambangan di Bursa Efek Indonesia). E-Jurnal Akuntansi Universitas Udayana, 4(1), 141-158.

Cokorda, G. B. P., Rasmini N. K., \& Astika, I. B. P. (2013). Pengaruh Corporate Social Responsibility Pada Price To Book Value Dengan Corporate Governance Sebagai Variabel Moderasi. E-Jurnal Ekonomi dan Bisnis, 2(5), 339-353. 
Cheng, M. \& Christiawan, Y. J. (2011). Pengaruh Pengungkapan Corporate Social Responsibility Terhadap Abnormal Return. Jurnal Akuntansi dan Keuangan, 13(1), 24-36.

Ghozali, I. (2013). Aplikasi Analisis Multivariate dengan Program IBM SPSS 21 Update PLS Regresi ( $7^{\text {th }}$ ed.). Semarang: Badan Penerbit Universitas Diponegoro.

Gibson, C. H. (2011). Financial Statement Analysis. (12 $2^{\text {th }}$ edition). Cengage Learning.

Hadi, N. (2011). Corporate Social Responsibility. Yogyakarta: Graha Ilmu.

Hamid, A. (2013). Pengaruh Tenur KAP dan Ukuran KAP Terhadap Kualitas Audit. Program Studi Akuntansi, Fakultas Ekonomi. Universitas Negeri Padang.

Karim, A. (2010). Pengaruh Good Corporate Governance Terhadap Kinerja Saham Perusahaan (Studi Empiris pada Saham LQ 45 di BEI). Jurnal Unimus, 1(1).

Rinaldy, Y. (2011). Pengaruh Pengungkapan Corporate Social Responsibility Terhadap Kepemilikan Institutional Pada Perusahaan Berkategori High Profile Yang Listing di Bursa Efek Indonesia. Skripsi S1. Fakultas Ekonomi, Universitas Diponegoro, Semarang.

Rustiarini, N. W. (2010). Pengaruh Corporate Governance Pada Hubungan Corporate Social Responsibility dan Nilai Perusahaan. Simposium Nasional Akuntansi XIII. AKPM_12, 1-24.
Susilawati, M. A. (2009). Pengaruh investment opportunity set. Corporate Social Responsibility terhadap nilai perusahaan dengan kepemilikan managemen, tipe industry sebagai variabel moderating. Jurnal Akuntansi dan Investasi, X(1), 30-44.

Tryfino. (2009). Cara Cerdas Berinvestasi Saham. Jakarta: Transmedia.

Republic of Indonesia. (2007). UU No. 40 Tahun 2007 tentang Perseroan Terbatas. Tambahan Lembaran Negara Republik Indonesia Nomor 4756. Sekretariat Negara. Jakarta.

Wibowo, A. J. (2012). Interaction Between Corporate Social responsibility Disclosure and Profitability of Indonesia Firms. UMT $11^{\text {th }}$

Yaparto, M., Frisko K, Dianne, \& Rizky Eriandini. (2013). Pengaruh Corporate Social Responsibility Terhadap Kinerja Keuangan Pada Sektor Manufaktur Yang Terdaftar Di Bursa Efek Indonesia Pada Periode 2010-2011. Calyptra: Jurnal Ilmiah Mahasiswa Universitas Surabaya, 2(1), 1-19.

Ziaee, M. (2014). The Effect of Audit Quality on The Performance of Listed Companies in Teheran Stock Exchange. International Letters of Social and Humanistic Sciences, 10(1), 36-43. 